\title{
Effect of Value Addition on the Functional Properties Nutritional and Sensory Quality of Indian Street Food (Pakoda)
}

\author{
Diksha and Rajni Modgil* \\ Department of Food Science, Nutrition and Technology, College of Community Science, CSK \\ Agricultural University, Palampur (H.P), India \\ *Corresponding author
}

\section{A B S T R A C T}

\section{Keywords}

Pakoda, street foods, Nutritional analysis, Physical characteristics, Organoleptic evaluation. Peroxide value, Anti-oxidant activity

\section{Article Info}

Accepted:

20 August 2020

Available Online:

10 September 2020
Street foods are ready to eat foods, beverage prepared and sold by venders and hawkers, especially in street and other public places. Pakoda or fritters are one of the most prominent snack/street food across the Indian subcontinent and enlighten its contribution in nutrition. In the present study an endeavor has been made to analyze the nutritional and functional quality of Pakoda available among street vendors and then its value addition with locally available healthy food material. For the analysis, samples were categorized into three categorize i.e. Control, street vendor, and value-added. Control and value-added samples were prepared in the laboratory/food lab and Pakodas procured from the local street vendors were categorized as street vendor samples. The triplicates of each category of samples were evaluated for the physical, functional, nutritional quality, and organoleptic acceptability. A significant difference existed in the samples procured from street vendors and samples prepared in the laboratory. The calorific value and DPPH in the street vendor sample were found to be $430.18 \mathrm{kcal}$ and $34.55 \%$ inhibition serially. The peroxide value, free fatty acid was inferior in the control and value-added sample and found higher in street vendor samples i.e. $8.92 \mathrm{meq} / \mathrm{kg}$ and $1.13 \%$ oleic acid respectively.

\section{Introduction}

Changed life style has resulted changes in the food habits which might have been due to non-availability of the time and altered food habits of the society due to cultural interactions, hectic activities and more women joining the jobs which resulted in tendency to eat outside. Eating outside the house particularly fast foods also known as street foods is due to their easy availability during shortage of time. So people like to eat outside to satisfy their appetite and hunger. Street foods are ready to eat foods, beverage prepared and sold by venders and hawkers, especially in street and other public places.In the era of expensive cafeterias, restaurants, and food hubs, people love to have street food as their favorite place for outdoor eating. The ability to provide snacks and meals at low and affordable prices and their availability at convenient places like offices, complexes, and 
market areas and tourist spots has allowed street foods to proliferate and persist. As like other developing countries, in India, the sale of raw and processed foodstuff by street vendors is a widespread phenomenon, known commonly as street foods, they range from snacks to full meal e.g. Samosa, Pakora, Tikki, Burger, Momos, Chole- bhaturey, Badapav, Chaatpapdi, Sevpuri, Gol-gappa, Dahi-bhalla and many more. In every part of the world, there's always the heritage of frying food. These foods are eaten not only for satisfying ones cravings for fried food but also for getting nutrition. Being conscious about health conditions it is important to know the nutritive value of street foods.

One of the most common strret food is Pakoda or dumpllings / fritters cPakoda also called pakoda, pakodi, fakkura, bhajiya, bhajji, bhaji or ponako is a fried snack (fritters), originating from the Indian subcontinent. It is an Indian dish containing pieces of vegetables or meat, chicken or fish and dipped in seasoned Bengal gram floor batter and the fried. These are generally served as snack during tea time. Some times it is also consumed as a part main dish like Kaddi pakoda and consumed during lunch or dinner. Although it is one of most liked snack but much work has not been reported on the chemical functional and nutritional quality of Pakoda and its value addition. So, in the present study, an attempt has been made to see the effect of value addition on the chemical functional and nutritional properties of Pakoda/ fritters.

\section{Materials and Methods}

\section{Preparation of samples}

Samples of Pakoda were procured from local street food vendors of Palampur city of Himachal Pradesh. Control and value-added samples were prepared in the laboratory
(Ingredients used are given in table 1). All the ingredients were weighed according to the quantity mentioned in table 1. Ingredients were mixed properly by adding the desired amount of water i.e. $90 \mathrm{ml}$. The oil was heated in a skillet over medium flame. The small portion of the mixture was taken into the hand and dropped gently into the oil. They were deep-fried under medium flame until golden brown. Figure 1 depicts the flow sheet for the preparation of Pakoda. After the procurement and preparation of control and value added samples in the laboratory, they were dried in a hot air oven at a temp. of $60^{\circ} \mathrm{C}$ for $8 \mathrm{hrs}$ and grounded into a fine powder. The dried samples were stored in airtight container still further analysis was done. The prepared sample was evaluated for various physicochemical characteristics. Functional properties, proximate composition, and nutritional quality.. All the analysis was done in triplicate.

\section{Physical characteristics}

Shape and Size were observed by visual perception. Weight in triplicate was measured on an electric scale. The length was measured using a measuring scale. Ten food sample of each treatment was taken. Thickness was taken at three different parts of Pakoda i.e. top central and lower part using a vernier caliper.

Water Absorption Capacity and Oil absorption Capacity was analyzed by the method of Sosulski and Garratt (1976) and Lin et.al (1974) respectively.

Proximate constituents' viz. moisture, ash, crude protein, crude fat, crude fiber was detected by standard procedures of AOAC (2010). The conversion factor of 6.25 was used to convert nitrogen into protein. Total carbohydrates were calculated by using the method given by Gopalan et al., (2007). 


\section{Nutritional composition}

The prepared samples were determined for their nutritional analysis viz., energy (O'shea and Maguire 1962), starch (Clegg 1956), Non-protein nitrogen (Pellet and young 1980), true protein (Crude protein NitrogenNPN), reducing sugars, non-reducing sugars, total sugars (Yemn and Willis 1954), ADF and NDF (Van Soest and Wine 1967), hemicellulose (NDF-ADF), peroxide value (AOAC 1999), free fatty acids (AOCS 1998), anti-oxidant activity (Miliauskas et al., 2008),(Khalaf et al., 2004).

\section{Minerals}

Calcium, phosphorus was analyzed by the method of Chen et al., (1956), iron and zinc were determined in the selected street foods. Determination of zinc and iron was done by using the atomic absorption spectrophotometer, Model 3100, Perkin Elmer. Calcium was detected by using the flame photometer, Mediflame, 127.

\section{Sensory Evaluation}

The samples were appraised organoleptically for the parameters like color, taste, flavor, texture, and overall acceptability. All three samples were evaluated for their sensory acceptability by a panel of ten semi-trained judges on a nine-point hedonic scale The index of acceptance (IA \%) was measured by using the following equation (Schumacher et al., 2010).

\section{Index of Acceptance $(\%)=\mathrm{M} / 9 \mathrm{X} 100$}

Where, $\mathrm{M}=$ the average of the evaluations carried out by the sensory panel.

\section{Statistical Analysis}

The attained data was possessed to Analysis of Variance (ANOVA) using OP stat software and was interpreted at $5 \%$ level of significance $(\mathrm{p} \leq 0.05)$.

\section{Results and Discussion}

\section{Physical and Functional properties}

Table 2 depicts the physical and functional properties i.e. color, shape, weight, length, thickness, and functional properties i.e. water absorption capacity and oil absorption capacity of Pakoda samples. Colour is the property subjected by an object of producing different sensations on the eye as it reflects or emits light. There was no distinctness in the color and shape of the control, street vendor, and value-added samples which were golden brown in color and had an irregular shape.

Weight is referred as a body's relative mass/the quantity of matter occupied by it, giving rise to a downward force or the bulkiness of a thing, the control, street vendor and value-added samples of Pakoda had 13, 18.25 and $15.12 \mathrm{~g}$ of weight respectively. A significant $(\mathrm{p} \leq 0.05)$ distinction was there in the control, street vendor, and value-added samples of Pakoda when compared with each other. The weight was maximum in the street vendor sample when compared with the control and value-added sample. The significantly $(p \leq 0.05)$ higher weight of street vendor Pakoda might have been due to its random shape.

The length of the control, street vendor, and value-added sample of Pakoda was 2.65, 2.53 , and $2.46 \mathrm{~cm}$, respectively. There was a non-significant difference $(\mathrm{p} \leq 0.05)$ in the control, street vendor and value-added sample when compared with each other. The length of the control sample of the Pakoda was maximum when compared with the rest of the samples. The thickness of control, a street vendor, and value-added sample was 0.87, 0.90 , and 1.25 , respectively. A significant 
$(p \leq 0.05)$ variation in the thickness was there when compared with each other. However, the thickness was maximum in value- added sample i.e. 1.25 inch and the lowest i.e. 0.87 inches in the control sample of Pakodas. The thickness of samples procured from the street -vendors was 0.90 inches.

The amount of water taken up by flour to achieve the desired consistency is referred as water absorption capacity, street vendor and value-added samples of Pakoda had 0.62, 2.57 , and $3.76 \mathrm{ml} / \mathrm{g}$ water absorption capacity, respectively. There was a significant $(\mathrm{p} \leq 0.05)$ variation in the Water absorption capacity of control when compared with street vendor and value-added sample of Pakoda. However, the variation was non-significant between the water absorption capacity of a street vendor and value-added samples when compared with each other. From the observed data, it has been found that the water absorption capacity was higher in value-added Pakoda and lower in the control sample. The difference in the water absorption capacity of these three samples might have been due to variation among the raw ingredients used for preparation.

Oil absorption capacity shows a defined correlation with emulsifying capacity for most proteins making it possible to predict emulsifying capacity simply. According to the data depicted in table 2 the oil absorption capacity of the samples i.e. Control, a street vendor, and value-added Pakoda was 1.33, 1.76 , and $2.16 \mathrm{ml} / 100 \mathrm{~g}$ respectively. There was a non- significant variation in the oil absorption capacity of these samples when compared with each other. The Oil absorption capacity of the value-added sample was nonsignificantly $(\mathrm{p} \leq 0.05)$ greater than the control and street vendor sample when compared with each other. This might have been due to the variation among the oil absorption capacity of raw ingredients used for preparation.

\section{Proximate composition}

The proximate composition is an important parameter for getting knowledge related to the nutritional and biochemical characteristics of food. Major components like moisture, ash, crude fat, crude fiber, and crude protein content were included in the proximate composition. Table 3 depicts the proximate composition of control, a street vendor, and a value-added sample of Pakoda.

The depicted data indicate that value addition resulted in a significant increase in crude ash, crude fiber, ether extract and crude protein content of Pakoda whereas a significant decrease was reported in the moisture and total carbohydrates. The difference in proximate constituents might have been due to variation in raw ingredients used. Deep fat fry of food leads to loss of moisture content. The difference in the moisture content might be due to the varied frying temperature. The high fiber content in the value-added sample might have been due to the addition of vegetables i.e. cauliflower, carrot, and onion. The value-added sample of Pakoda was found to have higher oil absorption capacity than the control and street vendor sample, which indicates having higher fat content in the values added samples of Pakoda than the rest of the samples. Carbohydrates in a control sample of Pakoda were maximum than the rest of the samples which might have been due to variation among the proximate composition of these samples (Table.3).

\section{Nutritional constituents}

Table 4 depicts the nutritional composition of control, street vendor, and value-added samples of Pakoda. NPN was maximum in the control sample of Pakoda when compared with value-added and street vendor Pakoda. However, a non-significant $(\mathrm{p} \leq 0.05)$ variation was there in the NPN content of value-added and street vendor samples of Pakoda. The 
difference in NPN content of the control, street vendor, and value-added samples might have been due to the variation among the raw ingredients used for preparation.

True protein, total sugars, reducing and nonreducing sugars, and all dietary fiber constituents were significantly $(\mathrm{p} \leq 0.05)$ increased after value addition (Table 4). The maximum calorific content of value-added Pakoda might have been due to its higher fat, protein, and sugar content as compared to control and street vendor Pakoda.

Table.1 List of ingredients used for preparing Pakoda

\begin{tabular}{|l|l|l|}
\hline Ingredients & Control & $\begin{array}{l}\text { Value- } \\
\text { added }\end{array}$ \\
\hline Gram flour & $\mathbf{1 0 0 g}$ & $\mathbf{7 5 g}$ \\
\hline Rice flour & - & $\mathbf{2 5 g}$ \\
\hline Cauliflower & - & $\mathbf{3 0 g}$ \\
\hline Carrot & - & $\mathbf{2 0 g}$ \\
\hline Onion & $\mathbf{1 5 0 g}$ & $\mathbf{5 0 g}$ \\
\hline Potatoes & - & $\mathbf{8 0 g}$ \\
\hline Spices & $\mathbf{2 g}$ each & $\mathbf{2 g}$ each \\
\hline Oil for frying & - & - \\
\hline
\end{tabular}

Table.2 Physical and functional properties

\begin{tabular}{|c|c|c|c|c|}
\hline Parameters & Control & Street Vendor & Value Added & $\mathrm{CD}(\mathrm{P} \leq \mathbf{0 . 0 5})$ \\
\hline Color & Golden Brown & Golden Brown & Golden Brown & - \\
\hline Shape & Irregular & Irregular & Irregular & - \\
\hline Weight (g) & 13 & 18.25 & 15.12 & 2.31 \\
\hline Length $(\mathbf{c m})$ & 2.65 & 2.53 & 2.46 & NS \\
\hline Thick-ness (inch) & 0.87 & 0.90 & 1.25 & 0.25 \\
\hline $\begin{array}{c}\text { Water absorption Capacity } \\
(\mathrm{ml} / \mathrm{g})\end{array}$ & 0.62 & 2.57 & 3.76 & 1.71 \\
\hline Oil absorption capacity (ml/g) & 1.33 & 1.76 & 2.16 & 1.05 \\
\hline
\end{tabular}

Table.3 Proximate composition

\begin{tabular}{|c|c|c|c|c|}
\hline Parameters & Control & Street vendor & Value Added & CD(P $\leq \mathbf{0 . 0 5})$ \\
\hline Moisture (\%) & 5.48 & 6.84 & 4.35 & 0.36 \\
\hline Crude Ash(\%) & 4.71 & 4.15 & 6.98 & 0.81 \\
\hline Crude Fiber (\%) & 1.14 & 1.20 & 2.46 & 0.50 \\
\hline Ether extract (\%) & 15.11 & 15.79 & 25.60 & 0.83 \\
\hline Crude Protein (\%) & 10.48 & 12.22 & 13.21 & 0.80 \\
\hline $\begin{array}{c}\text { Total carbohydrates } \\
(\%)\end{array}$ & 63.04 & 59.77 & 44.60 & 1.20 \\
\hline
\end{tabular}


Table.4 Nutritional composition

\begin{tabular}{|c|c|c|c|c|}
\hline Parameters & Control & Street vendor & Value-Added & CD(P $\leq \mathbf{0 . 0 5})$ \\
\hline NPN (\%) & 0.12 & 0.06 & 0.05 & NS \\
\hline True Protein (\%) & 9.73 & 11.83 & 12.85 & 0.99 \\
\hline Energy (Kcal/100g) & 430.14 & 430.18 & 459.41 & 0.92 \\
\hline Starch (\%) & 43.43 & 30.41 & 26.34 & 18.86 \\
\hline Reducing sugars (\%) & 1.90 & 2.70 & 4.23 & 1.29 \\
\hline Non- reducing sugars (\%) & 6.00 & 5.51 & 7.13 & 2.18 \\
\hline Total Sugars (\%) & 7.9 & 8.20 & 11.36 & 2.48 \\
\hline ADF (\%) & 2.35 & 3.32 & 4.00 & 1.75 \\
\hline NDF (\%) & 33.72 & 31.67 & 45.26 & 6.02 \\
\hline Hemi- cellulose (\%) & 31.37 & 28.35 & 41.26 & 5.58 \\
\hline Peroxide-value (meq/kg) & 3.88 & 8.92 & 4.67 & 2.48 \\
\hline FFA (\% Oleic acid) & 0.15 & 1.13 & 0.12 & 0.06 \\
\hline DPPH (\% inhibition) & 27.04 & 34.55 & 57.10 & 9.17 \\
\hline
\end{tabular}

Table.5 Macro and Micro minerals

\begin{tabular}{|c|c|c|c|c|}
\hline Parameters & Control & Street vendor & Value Added & $\mathbf{C D}(\mathbf{P} \leq \mathbf{0 . 0 5})$ \\
\hline Iron (mg/100g) & 4.18 & 6.18 & 16.47 & 0.21 \\
\hline Zinc (mg/100g) & 1.00 & 1.16 & 3.04 & 0.51 \\
\hline Calcium (mg/100g) & 192.75 & 206.50 & 257.82 & 11.84 \\
\hline Phosphorus (mg/100g) & 113.89 & 154.23 & 284.83 & 6.58 \\
\hline
\end{tabular}

Fig.1 Flowchart for preparation

\begin{abstract}
Weighing of ingredients according to the quantity mentioned in the table
$\downarrow$

All ingredients were mixed manually by adding a desirable amount of water

$\downarrow$

Deep-fried until golden brown
\end{abstract}

Figure 2 : Organoleptic Acceptability of Pakoda Samples

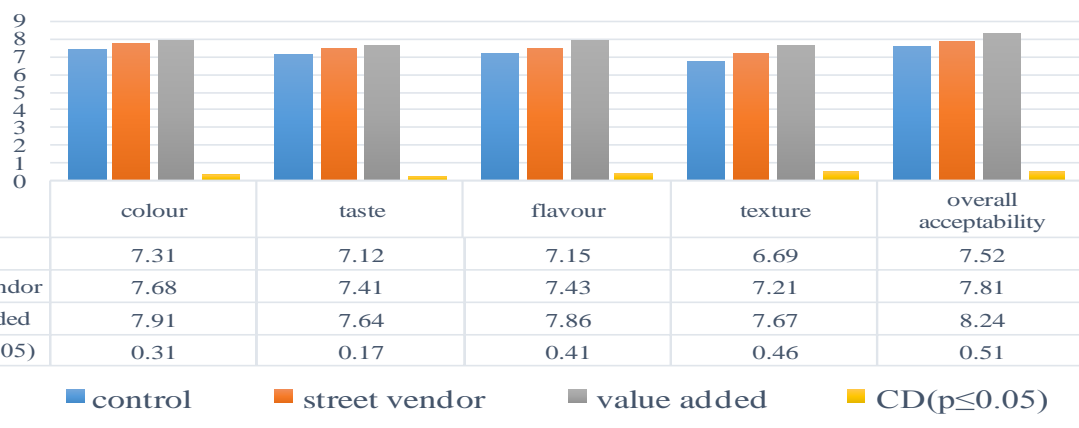




\section{Peroxide value}

For getting evidences of rancidity in unsaturated fats and oils determination of peroxide value is highly important. The double bonds found in fats and oils are responsible for autoxidation. Oils with maximum degree of unsaturation are susceptive to autoxidation. Peroxides are intermediates in the autoxidation reaction.

The difference in the peroxide value of the street vendor sample differs significantly $(p \leq 0.05)$ in comparison to the control and value-added sample. However, the difference in the peroxide value of control and the valueadded sample was non-significant $(\mathrm{p} \leq 0.05)$ when compared with control and street vendor. The higher peroxide value in the samples procured from street vendors might have been due to the use of auto-oxidized or preheated oil for frying.

\section{Free Fatty Acid (FFA)}

Table 4 reveals that the FFA content of Pakoda samples was $0.15,1.13$, and 0.12 percent, respectively. A significant $(p \leq 0.05)$ difference in the FFA content of the street vendor sample was there in comparison to the control and value-added samples of Pakoda. However, the content was also found maximum in the street vendor sample.

\section{DPPH}

It stands for 2,2-diphenyl-1-picryhhydrazyl which is a dark-colored crystalline powder when compared to stable free radical molecules. Its applications includes monitoring of chemical reactions involving radicals, most notably it is a common antioxidant essay, and standard of the position and intensity of electron paramagnetic resonance signals.
According to the data depicted in table 4 control, a street vendor and value-added Pakoda samples were 27.04, 34.55, and 57.10 percent of DPPH in the control, street vendor, and value-added samples. The content was significantly $(\mathrm{p} \leq 0.05)$ high in the value-added Pakoda followed by Pakoda procured from a street vendor as well as a control sample. However, a non-significant $\quad(p \leq 0.05)$ difference was found among the DPPH content of control and street vendor sample of Pakoda. The maximum content of DPPH in value-added Pakoda might have been due to the use of fresh oil for their preparation.

\section{Macro and micro minerals}

Table 5 shows the iron, zinc, calcium, and phosphorus content of Pakoda in different treatments. The value addition of Pakoda increased macro and microelements. The values of iron, zinc, calcium, and phosphorus were significantly $(\mathrm{p} \leq 0.05)$ higher in valueadded samples. Value addition of Pakoda with cauliflower, carrot, and potatoes caused a significant $(\mathrm{p} \leq 0.05)$ affect in increasing the iron, zinc, calcium and phosphorus content of the samples.

\section{Sensory evaluation}

Sensory evaluation is "a scientific discipline used to invoke, detect, and interpret response to characteristics of foods perceived by the senses of sight, smell, taste, touch, and hearing". The organoleptic acceptability of control, a street vendor, and value-added samples has been given in figure 2.The sensory scores for color, taste, and flavor and overall acceptability were significantly $(\mathrm{p} \leq 0.05)$ higher for value-added Pakoda as compared to sample procured from a street vendor as well as controlled samples. The higher color, taste, and overall acceptability score in the value-added sample might have been due to variation in the raw ingredient used. 
In conclusion the generally, street foods are consumed as a substitute for meals. However, they are cereal-based and some are also prepared by using pulses and vegetables with various preparation methods. In the case of Pakoda, it can be concluded that they are providing a significant portion of calories, carbohydrates, fats, and other nutrients and they can also be enriched with rice flour and some vegetables to increase the nutritive load in them.

\section{References}

AOAC. 2010. Official methods of analysis. Association of Official Analytical Chemist, Washington D.C.UK.14.068, 2057

AOAC.1999.Official methods of analysis, Association of Official Analytical Chemists, Washington

AOCS.1998.Official Method for analysis. American Oil Chemists' Society (5).

Chen PS, Tosibora TY and Warner H. 1956. Micro determination of phosphorus. Analytical Chemistry 28: 1756-1759

Clegg KM .1956. The application of the anthrone reagent to the estimation of starch in cereals. Journal of Food Science and Agriculture 7(1):40

Gopalan C, Rama Sastri BV, Balasubramanian SC.2007. Nutritive value of Indian foods 59-77

Khalaf AN, Shakya AK, Othman AL, ELAgbar Z, Faran H.2008. Antioxidant activity of some common plants. Turkish Journal of Biology 32: 51-55

Lin MJY, Humbert ES and Sosulski FW
.1974. Certain functional properties of sunflower meal products. International Journal of Food Science and Technology 39: 368-370.

Miliaukas GP, Venskutonis RP and Beek TA. 2004. Screening of radical scavenging activity of some medicinal and aromatic plant extracts. Food Chemistry 85(2): 231-237

O'shea JO and Maguire MP .1962. Determination of calorific value of foodstuff by chromic acid oxidation. Journal of the Science of Food and Agriculture 13: 530-532

Pellet LP and Young VR .1980. Nutritional evaluation of protein food. UN University Publication. P. 257.

Schumacher AB, Bradelli A, Macedo FC, Pieta L, Klug TV and Jong EV. 2010. Chemical and sensory evaluation of dark chocolate with addition of quinoa (Chenopodium quinoa Willd.). Journal of Food Science and Technology 47: 202-206

Sosulski FW, Garatt MO, Slinkard AE .1976. Functional properties of ten legume flours. International Journal of Food Science and Technology 9:66-69.

Van Soest PJ and Wine RH .1967. Use of detergent in the analysis of fibrous foods, determination of plant cell wall constituents. Journal of Association of Official Analytical Chemistry 50: 50

Yemn EC and Willis AJ .1954.The estimation of carbohydrates in plant extracts by anthrone. Biochemical Journal 57: 508514.

\section{How to cite this article:}

Diksha and Rajni Modgil. 2020. Effect of Value Addition on the Functional Properties Nutritional and Sensory Quality of Indian Street Food (Pakoda). Int.J.Curr.Microbiol.App.Sci. 9(09): 3106-3113. doi: https://doi.org/10.20546/ijcmas.2020.909.383 